\title{
Healthier chicken nuggets incorporated with chia (Salvia hispanica L.) flour and partial replacement of sodium chloride with calcium chloride
}

\author{
Julliane Carvalho Barros*, Isabela Rodrigues, Manoela Alves Pires, Letícia Aline Gonçalves, \\ Francisco Allan Leandro de Carvalho, Marco Antonio Trindade
}

Department of Food Engineering, College of Animal Science and Food Engineering of University of São Paulo

\section{A B S T R A C T}

\begin{abstract}
Chicken nuggets were reformulated by substituting the chicken skin with chia flour and partially substituting the $\mathrm{NaCl}$ with $\mathrm{CaCl}$. Four treatments were processed: Control $-1.5 \mathrm{~g} / 100 \mathrm{~g} \mathrm{NaCl}$, without the addition of chia flour; $\mathrm{CaCl}_{2}-75 \%$ substitution of $\mathrm{NaCl}$ by $\mathrm{CaCl}$; Chia $-50 \%$ replacement of chicken skin by chia flour; Chia $+\mathrm{CaCl}_{2}-75 \%$ replacement of $\mathrm{NaCl}$ by $\mathrm{CaCl}_{2}$ and $50 \%$ substitution of chicken skin by chia flour. The protein content increased with the incorporation of chia flour. Treatments $\mathrm{CaCl}_{2}$ and $\mathrm{Chia}+\mathrm{CaCl}_{2}$ presented reduced sodium content. Chicken nuggets containing chia flour showed an increase of $\alpha$-linolenic acid and can be labelled as "high omega- 3 content". Formulations Chia and Chia $+\mathrm{CaCl}_{2}$ presented lower sensory acceptance among the four formulations, but about $50 \%$ of consumers still considered them acceptable. Thus, the Chia $+\mathrm{CaCl}_{2}$ formulation could be recommended to consumers seeking healthier meat products, due to its high omega-3 and reduced sodium content.
\end{abstract}

Keywords: Breaded meat product; Healthiness; Omega-3; Sodium reduction; Sensory acceptance

\section{INTRODUCTION}

Meat and meat products are important sources of protein, vitamins and minerals but may contain high levels of fat, cholesterol, saturated fatty acids (SFA), salt $(\mathrm{NaCl})$ and nitrite, which can adversely affect human health (Jiménez-Colmenero et al., 2001). Excessive consumption of fat and sodium can cause various health issues, such as cardiovascular disease (Willett, 2012) and hypertension (He et al., 2012). Therefore, to improve the nutritional profile of meat products, these foods can be reformulated with health-promoting ingredients, such as fibre and vegetables, or components considered as harmful to health, like fat and additives, can be reduced or eliminated (Fernández-Ginés et al., 2005).

Chia (Salvia hispanica L.) flour can be incorporated into meat products to produce a healthier food product, due to the improved lipid profile (omega-3) and fibre content. Chia is an annual herbaceous plant belonging to the Labiatae family (Coates and Ayerza, 1996). Notably, it presents $30.9 \mathrm{~g} / 100 \mathrm{~g}$ total dietary fibre and a high proportion of $\alpha$-linolenic acid (63.4 g omega-3/100 g) (Mesías et al., 2016). Pintado et al. (2016a) demonstrated that the substitution of animal fat in frankfurters with chia flour $(10 \mathrm{~g} / 100 \mathrm{~g})$ adequately increased the fibre and omega- 3 content for labelling the product with certain nutritional and health claims. In a research conducted by our group, Barros et al. (2018) studying the different replacement levels ( 0 to $20 \%$ ) of chicken skin by chia flour verified that the addition of $10 \%$ chia flour in chicken nuggets was able to increase the product healthiness, by improving the lipid profile (increase omega- 3 content) and fibre enrichment, without affecting consumer acceptability.

Although the high sodium content in meat products can be decreased through the reduction and/or substitution of the $\mathrm{NaCl}$ with other chloride salts, such as $\mathrm{KCl}, \mathrm{CaCl}_{2}$ and $\mathrm{MgCl}_{2}$ (Aliño et al., 2010; Lazic et al., 2015; dos Santos et al., 2017), the flavour of the products may be negatively affected. This defect is mainly due to the use of divalent salts that cause a bitter taste (Yang and Lawless,

\footnotetext{
*Corresponding author:

Julliane Carvalho Barros, Department of Food Engineering, College of Animal Science and Food Engineering of University of São Paulo, 225, Duque de Caxias Norte, Jardim Elite, Postal code: 13635-900, Pirassununga, São Paulo, Brazil. Tel.: (+55) (19) 35654245.

E-mail: jullianebarros@usp.br
} 
2005). Consequently, the food is rejected by consumers (Horita et al., 2011; dos Santos et al., 2015). Previously, de Almeida et al. (2016) replaced the $\mathrm{NaCl}$ in salami by $\mathrm{KCl}$ and $\mathrm{CaCl}_{2}$, reducing the sodium content by $64 \%$ but causing an undesirable effect on the flavour. Conversely, Zanardi et al. (2010) verified that the bitterness parameter of Italian salami was unaffected by the partial substitution of $\mathrm{NaCl}$ with a salt mixture containing $\mathrm{NaCl}, \mathrm{KCl}, \mathrm{CaCl}_{2}$ and $\mathrm{MgCl}_{2}$ at the equivalent ionic strength of $2.7 \mathrm{~g} / 100 \mathrm{~g}$ $\mathrm{NaCl}$. In another study, also conducted in our research group, Barros et al. (2019) evaluated the substitution of 0 to $75 \%$ of $\mathrm{NaCl}$ by $\mathrm{CaCl}_{2}$ (with ionic strength equal to $1.5 \%$ $\mathrm{NaCl}$ ) and found that the maximum substitution tested was able to reduce 34\% sodium and the physicochemical parameters were not negatively affected.

In this context, the present study aimed to reformulate chicken nuggets to make it healthier by adding chia (Salvia hispanica L.) flour as a substitute for chicken skin, to improve the fatty acids profile (increase omega-3 content), and reduce sodium content by replacing sodium chloride with calcium chloride (with ionic strength equivalent to $1.5 \%$ $\mathrm{NaCl})$.

\section{MATERIALS AND METHODS}

The study was performed at the College of Animal Science and Food Engineering of the University of São Paulo (FZEA/USP), Brazil. Sensory evaluation of chicken nuggets was approved by the Ethics Committee for Research at FZEA/USP (Process 1.241.132).

\section{Reformulation and processing of chicken nuggets}

Four treatments of chicken nuggets were prepared (Table 1): Control - chicken nuggets with $1.5 \mathrm{~g} / 100 \mathrm{~g}$ $\mathrm{NaCl}$, without the addition of chia flour; $\mathrm{CaCl}_{2}-$ chicken nuggets with $75 \%$ substitution of $\mathrm{NaCl}$ by $\mathrm{CaCl}_{2}$ at an ionic strength equivalent to $1.5 \% \mathrm{NaCl}$; Chia - chicken nuggets with $50 \%$ replacement of chicken skin by chia flour; $\mathrm{Chia}+\mathrm{CaCl}_{2}$ - chicken nuggets with $75 \%$ replacement of $\mathrm{NaCl}_{\text {by }} \mathrm{CaCl}_{2}$ at an ionic strength equivalent to $1.5 \%$ $\mathrm{NaCl}$ and with $50 \%$ substitution of chicken skin by chia flour. The proportion of chia flour $(10 \mathrm{~g} / 100 \mathrm{~g}$; Barros et al., 2018) and $75 \% \mathrm{NaCl}$ replacement by $\mathrm{CaCl}_{2}$ at an equivalent ionic strength to 1.5\% $\mathrm{NaCl}$ (Barros et al., 2019) used in the reformulation of chicken nuggets was based on previous research conducted by our group. To illustrate, Barros et al. (2018) produced sensorially acceptable products that can be considered as a source of fibre and rich in $\alpha$-linolenic (omega-3) content by the replacement of chicken skin with up to $10 \mathrm{~g} / 100 \mathrm{~g}$ chia flour in chicken nuggets. Furthermore, the substitution of $\mathrm{NaCl}$ by $\mathrm{CaCl}_{2}$ did not negatively alter the physicochemical characteristics of the nuggets (Barros et al., 2019).

The other ingredients and proportions used in the present study, in all treatments, were $77.7 \mathrm{~g} / 100 \mathrm{~g}$ chicken breast fillet, $0.25 \mathrm{~g} / 100 \mathrm{~g}$ sodium tripolyphosphate (Cori Ingredientes, Rio Claro, Brazil), 0.05 g/100 g sodium erythorbate (Cori Ingredientes), $0.30 \mathrm{~g} / 100 \mathrm{~g}$ onion powder (New Max, Americana, Brazil), $0.05 \mathrm{~g} / 100 \mathrm{~g}$ white pepper (New Max) and $0.15 \mathrm{~g} / 100 \mathrm{~g}$ garlic powder (New Max). The raw material, including the chicken breast fillet, chicken skin and chia flour, were obtained from a local market in Pirassununga, Brazil. All salts used were food grade.

For the processing of the chicken nuggets, chicken skin and chicken breast fillet were ground in a grinder (4-and 8- $\mathrm{mm}$ diameter disc, respectively) and then mixed to homogeneity with the other ingredients. Portions (approximately $25 \mathrm{~g}$ ) of the mixture were shaped into nuggets and then coated with the following materials, obtained from Baptistella Alimentos (Itatiba, Brazil): pre-dust (type Liganex Gourmet), batter coating (type Liganex Gourmet) and breading (type Empanex Extra Crocante). The pick-up values, namely, the percentage of weight gain after coating, were around $36 \%$ for all treatments. The chicken nuggets were fried in palm fat (Doratta Fry, Agropalma, Belém, Brazil) at $180{ }^{\circ} \mathrm{C}$ until a minimum internal temperature of $72^{\circ} \mathrm{C}$.

After frying, the nuggets were packed in polyethylene plastic bags and stored frozen at $-18{ }^{\circ} \mathrm{C}$ until the analyses were complete. All analyses of the nuggets were performed after the frying step (product ready for consumption). The entire experiment (processing of all formulations) was repeated three times.

Table 1: Formulations of chicken nuggets with/without the addition of chia (Salvia hispanica L.) flour and different salts.

\begin{tabular}{|c|c|c|c|c|c|c|}
\hline \multirow[t]{3}{*}{ Treatments } & \multicolumn{6}{|c|}{ Ingredients } \\
\hline & \multirow[t]{2}{*}{ Chicken skin $(\mathrm{g} / 100 \mathrm{~g})$} & \multirow[t]{2}{*}{ Chia flour $(g / 100 \mathrm{~g})$} & \multicolumn{2}{|c|}{$\mathrm{NaCl}^{*}$} & \multicolumn{2}{|c|}{$\mathrm{CaCl}^{* *}$} \\
\hline & & & $\mathrm{g} / 100 \mathrm{~g}$ & IS $* * *$ & $\mathrm{~g} / 100 \mathrm{~g}$ & IS*** \\
\hline Control & 20 & - & 1.5 & 0.256 & - & - \\
\hline $\mathrm{CaCl}_{2}$ & 20 & - & 0.375 & 0.064 & 0.712 & 0.192 \\
\hline Chia & 10 & 10 & 1.5 & 0.256 & - & - \\
\hline $\mathrm{Chia}+\mathrm{CaCl}_{2}$ & 10 & 10 & 0.375 & 0.064 & 0.712 & 0.192 \\
\hline
\end{tabular}

${ }^{\star}$ Sodium chloride-Refimosal (Mossoró, Brazil). ${ }^{* *}$ Calcium chloride-ASHER Produtos químicos (Ribeirão Preto, Brazil). ${ }^{* \star *}$ IS-ionic strength 


\section{Physicochemical characterization of chicken nuggets Proximate composition and oil absorption}

The proximate composition was determined according to the Association of Official Analytical Chemists [AOAC] standard methods (Cunniff, 1998) for protein (981.10), ash (920.153) and moisture (950.46) contents. Lipid content was evaluated by following the Bligh and Dyer (1959) method. Oil absorption was calculated by the difference between the lipid content of the samples, before and after frying. All analyses were conducted in triplicate.

\section{Sodium content}

For evaluation of the sodium content, the chicken nugget samples were prepared as described by Krug and Rocha (2016) and evaluated using a radial inductively-coupled plasma optical emission spectrometer (Spectro Arcos, Spectro Analytical Instruments, Kleve, Germany). Duplicate analysis was undertaken, and the results were expressed as $\mathrm{mg} / 100 \mathrm{~g}$.

\section{Objective colour}

Samples were cut in half to evaluate the influence of the chia flour on the meat batter colour. The CIELAB $L^{*}$ (brightness), $a^{*}$ (greenness/redness) and $b^{*}$ (blueness/ yellowness) colour parameters were recorded using a portable Hunter Lab MiniScanXE colourimeter (Hunter Associates Laboratory, Inc., Reston, West Virginia, USA) set for illuminant D65, viewing angle $10^{\circ}$ and cell aperture $30 \mathrm{~mm}$. Eight readings were acquired.

\section{Water activity (aw) and $\mathrm{pH}$}

The $a_{w}$ of the nuggets was evaluated using an Aqualab (Decagon Devices, Pullman, WA, USA), with three repetitions per treatment. The $\mathrm{pH}$ values of the chicken nuggets were measured using a portable $\mathrm{pH}$ meter (HI 9916, Hanna Instruments, Europe). Quadruplicate readings were realised.

\section{Cooking yield}

The cooking yield was calculated by the difference between the weight of the fried nuggets and the raw nuggets (after coating), multiplied by 100 (Devatkal et al., 2011).

\section{Texture profile analysis (TPA)}

Instrumental TPA (hardness, cohesiveness, chewiness and springiness parameters) was determined using aTA. XT2i texturometer (Stable Micro Systems, Godalming, UK) equipped with a $30-\mathrm{mm}$-diameter aluminium probe moving at $0.3 \mathrm{~mm} / \mathrm{s}$. Six replicates were measured per treatment. Before analysis, the coating system of the nuggets was removed to avoid potential interference by the coating system, and the meat mixture was cut into 2 $\times 2 \mathrm{~cm}$ pieces.

\section{Fatty acid profile}

Lipids from each treatment of chicken nuggets were extracted by the method proposed by Bligh and Dyer (1959) and esterified (Shirai et al., 2005). Fatty acids were quantified by gas chromatography-mass spectrometry (GC-MS) using a gas chromatograph equipped with a G3243A MS detector (Agilent 7890 A GC System, Agilent Technologies, Inc., Santa Clara, CA, USA) anda fused silica capillary column (DB-23 Agilent 122-236; $60 \mathrm{~m} \times$ $250 \mathrm{~mm}$ inner diameter; J\&W Scientific, Inc., Folsom, CA, USA). The results were expressed as $\mathrm{g}$ fatty acids $/ 100 \mathrm{~g}$ oil extracted from the samples.

\section{Microbiological analyses}

Assurance of the microbiological safety of chicken nuggets was verified by enumeration of the pathogenic microorganisms: Salmonella sp. (using the commercial PCRbased system $\mathrm{Bax}^{\circledR} ;$ Kushida,2005); total coliforms and Escherichia coli using EC 6404 Petrifilm ${ }^{\mathrm{TM}}\left(3 \mathrm{M}^{\mathbb{}}\right.$ Health Care, St. Paul, MN, USA); Staphylococcus aureus using STX 6490 Petrifilm ${ }^{\mathrm{TM}}\left(3 \mathrm{M}^{\mathbb{B}}\right.$ Health Care). The aerobic psychrotrophic microorganisms were enumerated according to the AOAC official method 990.12 (AOAC, 2000). All microbiological results were expressed as colony-forming units per gram of sample $(\mathrm{CFU} / \mathrm{g})$.

\section{Sensory evaluation}

Chicken nuggets were sensorially assessed by the acceptance test, using a 9-point hedonic scale, ranging from $1=$ "dislike very much" to $9=$ "like very much". A total of 122 consumers (aged 18-38 years; $71 \%$ female and $29 \%$ male) that had interest, availability and a habit of consuming chicken nuggets evaluated the meat products for internal appearance, aroma, texture, flavour and overall quality attributes. Each panellist agreed and signed the Free and Informed Consent Form before the analysis. For sensory analysis, the nuggets were heated in an electric oven and kept at $60^{\circ} \mathrm{C}$, until the evaluation. The samples were coded with random three-digit numbers and served monadically to the consumers, in a randomised complete block design.

\section{Statistical analysis}

Statistical analyses were accomplished using the Statistical Analysis System (SAS version 9.4, SAS Institute Inc., Cary, NC, USA). Normal distribution and variance homogeneity were previously tested (Shapiro-Wilk). Data from physicochemical analyses were submitted to analysis of variance (ANOVA) using the MIXED procedure in which the treatments were considered as a fixed effect and the replicates as a random effect. Tukey's test followed when the ANOVA showed a significant effect $(p<0.05)$. To complement the sensory results, the frequencies of rejection (scores 1-4), indifference (score of 5) and 
acceptance (scores 6-9) of the different treatments of chicken nuggets were assessed, based on the overall quality attribute (Galvão et al., 2014).

\section{RESULTS AND DISCUSSION}

\section{Physicochemical characterization of chicken nuggets}

The physicochemical results of the different treatments of chicken nuggets, with or without the addition of chia flour and different salts, are presented in Table 2. There were no major differences $(p>0.05)$ in the oil absorption, which ranged from $9.46-10.30 \mathrm{~g} / 100 \mathrm{~g}$. Treatment $\mathrm{CaCl}_{2}$ had a similar $(p>0.05)$ lipid content to $\mathrm{Chia}+\mathrm{CaCl}_{2}$ but differed $(p<0.05)$ from those of the Control and Chia treatments. The nuggets containing chia flour had an equal amount of lipid $(p>0.05)$ as the Control formulation, as the lipid content originating from the chia flour $(32.01 \mathrm{~g} / 100 \mathrm{~g}$; Costantini et al., 2014) was the same as that in the chicken skin (31.44 g/100 g; Choi et al., 2016). Different to the present study, in which the nuggets were fried in oil, no noticeable differences in fat content $(8.96-9.23 \mathrm{~g} / 100 \mathrm{~g})$ were found among steam-cooked, low-fat chicken nuggets reformulated with a salt substitute blend $(\mathrm{KCl}$, citric acid, tartaric acid and sucrose) and pea hull flour (8, 10 and $12 \mathrm{~g} / 100 \mathrm{~g})$ (Verma et al., 2015).

The added chia flour increased $(p<0.05$; Chia and $\mathrm{Chia}+\mathrm{CaCl}_{2}$ ) the protein content of the chicken nuggets when compared with the Control formulation, due to the high protein content of chia flour $(19.8 \mathrm{~g} / 100 \mathrm{~g}$; Mesías et al., 2016). However, all evaluated formulations of chicken nuggets can be claimed as "high protein content", according to Brazilian legislation, which recommends a minimum of $12 \mathrm{~g}$ protein/100 g product (Brasil, 2012). The same was observed by Pintado et al. (2016a), in frankfurters containing $10 \mathrm{~g} / 100 \mathrm{~g}$ chia flour, regardless of the reformulation process.

Both, the replacement of $\mathrm{NaCl}$ by $\mathrm{CaCl}_{2}$ and chicken skin by chia flour, decreased $(p<0.05)$ the moisture content of chicken nuggets $\left(\mathrm{CaCl}_{2}\right.$, Chia and $\mathrm{Chia}+\mathrm{CaCl}_{2}$ treatments) (Table 2). Two explanations can be provided for this behaviour. One reason is the presence of $\mathrm{CaCl}_{2}$ and the low amount of $\mathrm{NaCl}$ used in the formulation. In a study by Schut (1976), the use of divalent salts, such as $\mathrm{CaCl}_{2}$, decreased the water-holding capacity while the opposite (increased water-holding capacity) occurred in the presence of high amounts of $\mathrm{NaCl}$ (Puolanne and Peltonen, 2013). The second explanation is the lower moisture content of chia flour (6.82 g/100 g; Segura-Campos et al., 2014) when compared with the chicken skin $(54.22 \mathrm{~g} / 100 \mathrm{~g}$; Choi et al., 2016). Verma et al. (2012a) also verified a decrease in the moisture content of low-fat chicken nuggets when replacing $\mathrm{NaCl}$ with a salt mixture $(\mathrm{KCl}$, citric acid, tartaric acid and sucrose), and a further reduction with the incorporation of chickpea hull flour $(5,7.5$ and $10 \mathrm{~g} / 100 \mathrm{~g})$. In that study, it was thought that the high $\mathrm{NaCl}$ content improved the extraction of protein from the meat, leading to more

Table 2: Physicochemical results of the different treatments of chicken nuggets, with or without the addition of chia flour (Salvia hispanica L.) and different salts

\begin{tabular}{|c|c|c|c|c|c|}
\hline \multirow[t]{2}{*}{ Analysis } & \multicolumn{5}{|c|}{ Treatments } \\
\hline & Control & $\mathrm{CaCl}_{2}$ & Chia & $\mathrm{Chia}+\mathrm{CaCl}_{2}$ & SEM \\
\hline Oil absorption & $9.46^{a}$ & $10.30^{\mathrm{a}}$ & $9.54^{\mathrm{a}}$ & $10.20^{\mathrm{a}}$ & 0.30 \\
\hline \multicolumn{6}{|c|}{ Proximate composition $(\mathrm{g} / 100 \mathrm{~g})$} \\
\hline Lipids & $16.27^{\mathrm{b}}$ & $17.26^{\mathrm{a}}$ & $15.95^{\mathrm{b}}$ & $16.68^{\mathrm{ab}}$ & 0.31 \\
\hline Protein & $17.21^{\mathrm{b}}$ & $18.03^{\mathrm{ab}}$ & $18.61^{\mathrm{a}}$ & $18.53^{\mathrm{a}}$ & 0.32 \\
\hline Moisture & $46.22^{\mathrm{a}}$ & $44.31^{\mathrm{b}}$ & $42.86^{c}$ & $42.20^{c}$ & 0.30 \\
\hline Ash & $2.39^{\mathrm{b}}$ & $2.00^{d}$ & $2.72^{\mathrm{a}}$ & $2.30^{c}$ & 0.01 \\
\hline Sodium (mg/100 g) & $764.83^{\mathrm{a}}$ & $457.67^{b}$ & $759.33^{a}$ & $436.00^{c}$ & 33.02 \\
\hline \multicolumn{6}{|l|}{ Objective colour } \\
\hline$L^{*}$ & $75.03^{b}$ & $77.04^{\mathrm{a}}$ & $54.42^{\mathrm{d}}$ & $63.44^{\mathrm{c}}$ & 0.78 \\
\hline$a^{*}$ & $2.42^{\mathrm{c}}$ & $2.48^{c}$ & $3.86^{\mathrm{a}}$ & $3.22^{\mathrm{b}}$ & 0.09 \\
\hline$b^{*}$ & $20.68^{a}$ & $19.91^{b}$ & $16.16^{c}$ & $16.76^{c}$ & 0.09 \\
\hline Cooking yield (\%) & $88.52^{\mathrm{ab}}$ & $87.01^{b}$ & $90.51^{a}$ & $89.51^{a}$ & 0.61 \\
\hline $\mathrm{pH}$ & $5.15^{\mathrm{a}}$ & $5.34^{a}$ & $5.35^{\mathrm{a}}$ & $5.28^{a}$ & 0.12 \\
\hline$a w$ & $0.953^{a}$ & $0.954^{a}$ & $0.946^{b}$ & $0.953^{a}$ & 0.00 \\
\hline \multicolumn{6}{|c|}{ TPA - Texture profile analysis } \\
\hline Hardness (kg) & $4.67^{\mathrm{ab}}$ & $4.16^{\mathrm{b}}$ & $5.30^{a}$ & $4.31^{\mathrm{b}}$ & 0.13 \\
\hline Cohesiveness & $0.63^{a}$ & $0.60^{\mathrm{a}}$ & $0.55^{\mathrm{b}}$ & $0.54^{\mathrm{b}}$ & 0.01 \\
\hline Chewiness (kg.mm) & $2.01^{a}$ & $1.65^{\mathrm{ab}}$ & $1.80^{\mathrm{a}}$ & $1.34^{\mathrm{b}}$ & 0.06 \\
\hline Springiness $(\mathrm{mm})$ & $0.68^{a}$ & $0.65^{\mathrm{ab}}$ & $0.60^{\mathrm{bc}}$ & $0.58^{c}$ & 0.01 \\
\hline
\end{tabular}

a,b,ceEqual letters on the same row indicate that there is no significant difference at $5 \%$. SEM: Standard error of mean. Control-1.5 g/100 g NaCl+20 g/100 g chicken skin; $\mathrm{CaCl}_{2}-0.375 \mathrm{~g} / 100 \mathrm{~g} \mathrm{NaCl}+0.712 \mathrm{~g} / 100 \mathrm{~g} \mathrm{CaCl}_{2} ;$ Chia-10 g/100 g chicken skin+10 g/100 g chia flour; Chia $+\mathrm{CaCl}_{2}-0.375 \mathrm{~g} / 100 \mathrm{~g} \mathrm{NaCl}+0.712$ $\mathrm{g} / 100 \mathrm{~g} \mathrm{CaCl}_{2}+10 \mathrm{~g} / 100 \mathrm{~g}$ chia flour 
moisture-binding compared with the poor water-binding of the chickpea hull flour.

The ash content in chicken nuggets was affected $(p<0.05)$ by both substitutions $\left(\mathrm{NaCl}\right.$ by $\mathrm{CaCl}_{2}$, and chicken skin by chia flour). Treatments $\mathrm{CaCl}_{2}$ and $\mathrm{Chia}+\mathrm{CaCl}_{2}$ had less $(p<0.05)$ ash than the other formulations because of the lower amount of $\mathrm{CaCl}_{2}$ needed to replace $\mathrm{NaCl}$ (to maintain an equivalent ionic strength). In low-fat chicken nuggets with salt replacement (mixture of $\mathrm{KCl}$, citric acid, tartaric acid and sucrose) and added bottle gourd (5, 7.5 and $10 \mathrm{~g} / 100 \mathrm{~g}$ ), Verma et al. (2012b) found that only the formulation containing $\mathrm{NaCl}$ substitution by the salt mixture had a reduced ash content relative to the control. Likewise, Gimeno et al. (1999) lowered the ash content of dry fermented sausages by partial replacement of the $\mathrm{NaCl}$ with $\mathrm{KCl}$ and $\mathrm{CaCl}_{2}$ (ionic strength $=2.6 \%$ $\mathrm{NaCl})$. The increase $(p<0.05)$ in ash content of the Chia formulation is caused by the high mineral content of chia flour (4.26 g/100 g; Costantini et al., 2014). Also consistent with the present findings, Pintado et al. (2016a) determined an increase in the ash content of Control (no chia flour) frankfurters reformulated to incorporate chia flour $(10 \mathrm{~g} / 100 \mathrm{~g})$.

Treatments $\mathrm{CaCl}_{2}$ and Chia $+\mathrm{CaCl}_{2}$ had less $(p<0.05$; Table 2) sodium than the Control formulation. However, the reduction of $75 \% \mathrm{NaCl}$ in these formulations was only able to reduce $40 \%$ and $43 \%$ of the sodium content, respectively. This lower than expected reduction might be explained by the other sources of sodium in the formulation, such as sodium tripolyphosphate, sodium erythorbate, the raw meat material and the coating system. Nonetheless, the chicken nuggets with $75 \%$ replacement of $\mathrm{NaCl}$ by $\mathrm{CaCl}_{2}$ could be claimed as "reduced sodium" (European Commission, 2006; Brasil, 2012). In addition, treatments $\mathrm{CaCl}_{2}$ and $\mathrm{Chia}+\mathrm{CaCl}_{2}$ comply with the recommended maximum sodium content of $650 \mathrm{mg} / 100 \mathrm{~g}$ in breaded meat products, established by the Brazilian government agencies and food industries (Brasil, 2013). As exemplified by Horita et al. (2014), the presence of additives used in the reformulation of frankfurter sausages were responsible for the underachieving sodium reduction. On the contrary, Campagnol et al. (2017) achieved a $55 \%$ reduction in sodium content when $50 \% \mathrm{NaCl}$ was replaced by disodium inosinate/disodium guanylate and transglutaminase in low-fat bologna-type sausages enriched with fructooligosaccharides.

There were notable differences $(p<0.05)$ in the brightness parameter $\left(L^{*}\right)$ (Table 2) among the different treatments of chicken nuggets, which can be explained by the addition of chia flour (dark appearance; Fig. 1) and $\mathrm{CaCl}_{2}$ (whitish appearance). In corroboration with this result, Pintado et al.

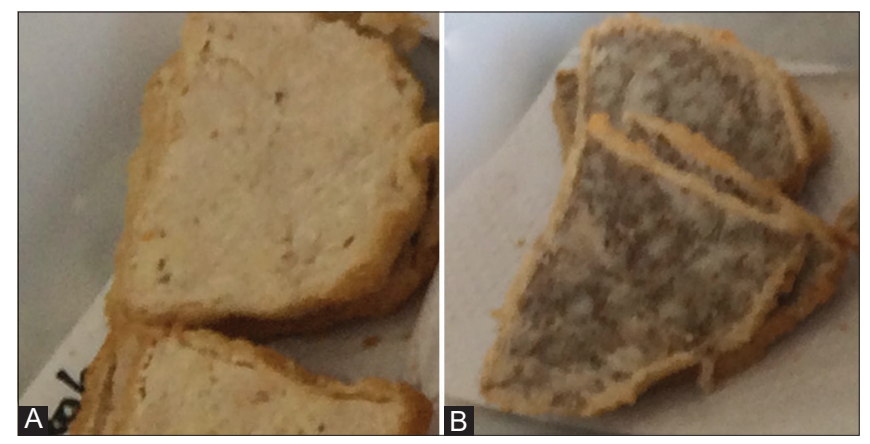

Fig 1. Internal appearance of chicken nuggets with and without addition of chia flour. A - Chicken nuggets without chia flour. B - Chicken nuggets with addition of $10 \mathrm{~g} / 100 \mathrm{~g}$ chia flour.

(2016a) confirmed a decrease in $L^{*}$ values of frankfurters containing $10 \mathrm{~g} / 100 \mathrm{~g}$ chia flour, irrespective of the incorporation strategy. Gimeno et al. (1999) verified an increase in the mean $L^{*}$ value of dry fermented sausages, associated with the partial replacement of $\mathrm{NaCl}$ with $\mathrm{KCl}$ and $\mathrm{CaCl}_{2}$.

Colour parameter $a^{*}$ was higher $(p<0.05)$ in treatments Chia and Chia $+\mathrm{CaCl}_{2}$ than the Control and $\mathrm{CaCl}_{2}$, which shared similar $(p>0.05) a^{*}$ values to each other. Conversely, there was a decrease $(p<0.05)$ in the mean $b^{*}$ values for $\mathrm{CaCl}_{2}$, Chia and $\mathrm{Chia}+\mathrm{CaCl}_{2}$ treatments in comparison to the Control treatment. An increase in $a^{*}$ and decrease in $b^{*}$ was previously reported by Barros et al. (2018) following the addition of chia flour $(10 \mathrm{~g} / 100 \mathrm{~g})$ to chicken nuggets. Horita et al. (2014) found no differences in $a^{*}$ and $b^{*}$ among frankfurter sausages reformulated by the substitution of $\mathrm{NaCl}$ with a salt blend containing $\mathrm{NaCl}, \mathrm{KCl}$ and $\mathrm{CaCl}_{2}$.

Treatment $\mathrm{CaCl}_{2}$ resulted in a lower $(p<0.05)$ cooking yield than Chia and $\mathrm{Chia}+\mathrm{CaCl}_{2}$ formulations (Table 2). This observed difference can be justified by the presence of chia flour and the replacement of $\mathrm{NaCl}$ by $\mathrm{CaCl}_{2}$. Chia flour has excellent water-retention and water-absorption capacities (Capitani et al., 2012) associated with its high fibre content (34.46 g/100 g, dry basis; Segura-Campos et al., 2014), which could have improved the cooking yield. The use of divalent salts, like $\mathrm{CaCl}_{2}$ and $\mathrm{MgCl}_{2}$ (Hamm, 1986), and the reduction of the $\mathrm{NaCl}$ content (Ruusunen et al., 2005), probably decreased the water-holding capacity of meat, increasing the cooking loss. However, all reformulated nuggets $\left(\mathrm{CaCl}_{2}\right.$, Chia and $\left.\mathrm{Chia}+\mathrm{CaCl}_{2}\right)$ did not differ $(\phi>0.05)$ from the Control. In contrast, in earlier work, low-fat chicken nuggets having $40 \% \mathrm{NaCl}$ substitution by a salt blend ( $\mathrm{KCl}$, citric acid, tartaric acid and sucrose) and the incorporation of apple pulp (8,10 and $12 \mathrm{~g} / 100 \mathrm{~g}$ ) presented low cooking yield in comparison to the control, as a result of the lower emulsion stability of the reformulated products (Verma et al., 2010). 
All treatments had the same $(p>0.05)$ mean $\mathrm{pH}$ value (Table 2). In line with this result, Kim et al. (2015) found no difference in the $\mathrm{pH}$ values among chicken nuggets reformulated with various contents $(2.5,5,7.5$ and $10 \%)$ of chicken skin and wheat fibre mixture. The $a_{w}$ of the Chia treatment decreased $(p<0.05)$ relative to the other treatments, which did not differ $(p>0.05)$ among themselves. This observation can be attributed to the high water-retention capacity of chia flour and the relatively low moisture content of Chia nuggets. Similarly, Barros et al. (2018) verified a decrease in the $a_{w}$ of nuggets with at least $15 \%$ chia flour addition.

Regarding the TPA analyses, the hardness parameter results obtained for Control treatment did not differ $(p>0.05)$ from all other evaluated reformulations $\left(\mathrm{CaCl}_{2}\right.$, Chia and $\mathrm{Chia}+\mathrm{CaCl}_{2}$ ). The addition of up to $10 \mathrm{~g} / 100 \mathrm{~g}$ of chia flour in chicken nuggets has not interfered with the hardness of the meat product when compared with the nuggets without chia flour addition (Barros et al., 2018). Instead, in the present study, the Chia treatment presented higher $(p<0.05)$ hardness values in comparison to $\mathrm{CaCl}_{2}$ and $\mathrm{Chia}+\mathrm{CaCl}_{2}$, probably owing to a lower myofibrillar protein extraction ability of the $\mathrm{CaCl}_{2}$ when compared with that of $\mathrm{NaCl}$.
The treatments containing chia flour (Chia and $\left.\mathrm{Chia}+\mathrm{CaCl}_{2}\right)$ presented low $(p<0.05)$ mean values for cohesiveness and springiness. Similarly, Pintado et al. (2016a) recorded a reduction in the cohesiveness and springiness of control frankfurters when $10 \%$ chia flour was incorporated. Also, low-fat chicken nuggets exhibited a decreased cohesiveness when reformulated with a salt substitute blend $(\mathrm{KCl}$, citric acid, tartaric acid and sucrose) and enriched with apple pulp (8,10 and $12 \mathrm{~g} / 100 \mathrm{~g}$ ) (Verma et al., 2010).

The chewiness of $\mathrm{Chia}+\mathrm{CaCl}_{2}$ was similar to that of $\mathrm{CaCl}_{2}$ $(p>0.05)$ but differed $(p<0.05$; Table 2$)$ from those of the Control and Chia formulations. Likewise, reformulation with $40 \%$ replacement of $\mathrm{NaCl}$ by a salt blend $(\mathrm{KCl}$, citric acid, tartaric acid and sucrose) and added with bottle gourd $(5,7.5$ and $10 \mathrm{~g} / 100 \mathrm{~g})$ decreased the chewiness of low-fat chicken nuggets, according to Verma et al. (2012b).

\section{Fatty acid profile}

The fatty acid profiles of the different chicken nuggets are shown in Table 3. All treatments had the same total SFA content as each other $(p>0.05)$ while the total monounsaturated fatty acid (MUFA) content of treatment $\mathrm{Chia}+\mathrm{CaCl}_{2}$ differed $(p<0.05)$ from that of the Control formulation. Contrarily, Pintado et al. (2016a) observed a

Table 3: Fatty acid profiles of the different treatments of chicken nuggets, with or without the addition of chia flour (Salvia hispanica L.) and different salts

\begin{tabular}{|c|c|c|c|c|c|}
\hline \multirow[t]{2}{*}{ g/100 g Fatty acid } & \multicolumn{5}{|c|}{ Treatments } \\
\hline & Control & $\mathrm{CaCl}_{2}$ & Chia & $\mathrm{Chia}+\mathrm{CaCl}_{2}$ & SEM \\
\hline Lauric (C12:0) & $0.24^{\mathrm{ab}}$ & $0.17^{\mathrm{bc}}$ & $0.28^{a}$ & $0.12^{c}$ & 0.02 \\
\hline Myristic (C14:0) & $0.85^{a}$ & $0.73^{a b}$ & $0.88^{a}$ & $0.67^{b}$ & 0.03 \\
\hline Pentadecanoic (C15:0) & $0.08^{a}$ & $0.07^{a}$ & $0.08^{a}$ & $0.06^{a}$ & 0.00 \\
\hline Palmitic (C16:0) & $32.09^{a}$ & $32.81^{a}$ & $31.98^{a}$ & $31.66^{a}$ & 0.40 \\
\hline Margaric $(\mathrm{C} 17: 0)$ & $0.15^{\mathrm{a}}$ & $0.14^{\mathrm{a}}$ & $0.16^{a}$ & $0.11^{\mathrm{a}}$ & 0.01 \\
\hline Stearic (C18:0) & $8.11^{\mathrm{a}}$ & $7.61^{\mathrm{a}}$ & $7.05^{a}$ & $7.67^{a}$ & 0.20 \\
\hline Arachidic (C20:0) & $0.24^{a}$ & $0.25^{\mathrm{a}}$ & $0.38^{a}$ & $0.26^{\mathrm{a}}$ & 0.02 \\
\hline$\Sigma$ SFA & $41.75^{\mathrm{a}}$ & $43.93^{a}$ & $40.30^{\mathrm{a}}$ & $40.55^{a}$ & 0.81 \\
\hline Miristoleic (C14:1 n7) & $0.09^{a}$ & $0.13^{a}$ & $0.14^{a}$ & $0.07^{a}$ & 0.02 \\
\hline Palmitoleic (C16:1 n7) & $0.35^{a}$ & $0.42^{\mathrm{a}}$ & $0.33^{a}$ & $0.32^{a}$ & 0.01 \\
\hline 7-hexadecenoic (C16:1 n9) & $2.06^{a}$ & $1.95^{a}$ & $1.24^{b}$ & $1.13^{b}$ & 0.12 \\
\hline Heptadecenoic (C17:1 n7) & $0.10^{\mathrm{a}}$ & $0.10^{\mathrm{a}}$ & $0.07^{a}$ & $0.07^{a}$ & 0.01 \\
\hline Oleic (C18:1 n9) & $36.15^{\mathrm{a}}$ & $36.01^{\mathrm{a}}$ & $34.08^{b}$ & $35.56^{c}$ & 0.57 \\
\hline Vaccenic (C18:1 n7) & $0.10^{\mathrm{a}}$ & $0.73^{\mathrm{a}}$ & $0.14^{a}$ & $0.59^{a}$ & 0.13 \\
\hline Paullinic (C20:1 n7) & $0.12^{b}$ & $0.19^{a b}$ & $0.26^{a}$ & $0.14^{b}$ & 0.02 \\
\hline$\Sigma$ MUFA & $38.95^{\mathrm{a}}$ & $37.79^{\mathrm{ab}}$ & $36.22^{\mathrm{ab}}$ & $33.88^{b}$ & 0.68 \\
\hline Linoleic (C18:2 n6*) & $17.82^{\mathrm{a}}$ & $17.11^{\mathrm{a}}$ & $14.06^{\mathrm{a}}$ & $15.54^{\mathrm{a}}$ & 0.56 \\
\hline$\gamma$-linolenic (C18:3 n6) & $0.11^{\mathrm{a}}$ & $0.14^{\mathrm{a}}$ & $0.12^{\mathrm{a}}$ & $0.10^{\mathrm{a}}$ & 0.01 \\
\hline$\alpha$-linolenic (C18:3 n3**) & $1.21^{c}$ & $0.92^{c}$ & $7.85^{b}$ & $9.83^{a}$ & 1.04 \\
\hline Arachidonic (C20:4 n6) & $0.16^{\mathrm{a}}$ & $0.13^{a}$ & $0.11^{\mathrm{a}}$ & $0.11^{\mathrm{a}}$ & 0.01 \\
\hline$\Sigma$ PUFA & $19.30^{\mathrm{bc}}$ & $18.29^{\circ}$ & $22.62^{\mathrm{ab}}$ & $25.58^{a}$ & 0.86 \\
\hline PUFA/SFA & $0.46^{\mathrm{b}}$ & $0.43^{b}$ & $0.59^{\mathrm{ab}}$ & $0.64^{\mathrm{a}}$ & 0.03 \\
\hline$n 6: n 3^{* * *}$ & 14.73 & 18.60 & 1.79 & 1.58 & - \\
\hline
\end{tabular}

a,b,c Equal letters on the same row indicate that there is no significant difference at $5 \%$. SEM: Standard error of mean. Control-1.5 $\mathrm{g} / 100 \mathrm{~g} \mathrm{NaCl}+20 \mathrm{~g} / 100 \mathrm{~g}$ chicken skin; $\mathrm{CaCl}_{2}-0.375 \mathrm{~g} / 100 \mathrm{~g} \mathrm{NaCl}+0.712 \mathrm{~g} / 100 \mathrm{~g} \mathrm{CaCl}$; Chia-10 g/100 g chicken skin $+10 \mathrm{~g} / 100 \mathrm{~g}$ chia flour; Chia+CaCl $-0.375 \mathrm{~g} / 100 \mathrm{~g} \mathrm{NaCl}+0.712$ $\mathrm{g} / 100 \mathrm{~g} \mathrm{CaCl}_{2}+10 \mathrm{~g} / 100 \mathrm{~g}$ chia flour. "n6=omega-6. "n3=omega-3. "*n6:n3=linoleic (C18:2): $\alpha$-linolenic (C18:3) 
decrease in the SFA and MUFA contents of frankfurters added with chia flour $(10 \mathrm{~g} / 100 \mathrm{~g})$. This difference is probably related to the different meat products studied, which have different raw materials.

The chicken nuggets containing chia flour showed an increase $(p<0.05)$ in the total polyunsaturated fatty acid (PUFA) content, attributed to the higher $(p<0.05)$ $\alpha$-linolenic fatty acid level (omega-3), considering the high content of this fatty acid in chia flour $(63.4 \mathrm{~g} / 100 \mathrm{~g}$; Mesías et al.,2016). The same was realised by Barros et al. (2018) in chicken nuggets added with chia flour $(5-20 \mathrm{~g} / 100 \mathrm{~g})$. The consumption of a $130 \mathrm{~g}$ portion (Brasil, 2003) of Chia and $\mathrm{Chia}+\mathrm{CaCl}_{2}$ nuggets would make a substantial contribution to the daily dietary intake of $\alpha$-linolenic acid, given the total lipid presented by these products is around $16 \%$, and the omega- 3 content is around $1.7 \mathrm{~g} / 130 \mathrm{~g}$, which is close to the $2.22 \mathrm{~g} /$ day recommended by Simopoulos et al. (1999). Furthermore, the Chia and $\mathrm{Chia}+\mathrm{CaCl}_{2}$ treatments can be labelled as "high omega-3 content" (Commission Regulation (EU), 2010; Brasil, 2012).

The addition of chia flour to chicken nuggets increased $(p<0.05)$ the PUFA: SFA ratio and decreased the omega6:omega-3 ratio. However, the PUFA: SFA ratio of the different chicken nugget treatments does not meet the recommendations set by the Food and Agricultural Organisation of the United Nations/World Health Organisation (FAO/WHO, 2008) that consumption of SFAs must be $<10 \%$, and PUFAs between 6 and $11 \%$, respectively. Therefore, it is possible to infer that the PUFA: SFA ratio in the diet should be $>1$. However, the omega-6:omega-3 ratios of the chicken nuggets added with chia flour comply with the recommended ratio of $\leq 5: 1$ (WHO/FAO, 1994). Based on Simopoulos (2004), a high intake of omega- 6 fatty acids, which results in a high omega-6:omega-3 ratio, is associated with several diseases, such as cardiovascular disease, cancer, diabetes, obesity and depression. For this reason, Simopoulos (2004) reported that lower ingestion of omega- 6 and increase of omega- 3 might reduce the risk of these chronic diseases.

\section{Microbiological analyses}

The microbiological analyses affirmed that the addition of chia flour and $\mathrm{CaCl}_{2}$, as a substitute of chicken skin and $\mathrm{NaCl}$, respectively, did not affect the microbial growth in chicken nuggets, presenting total coliforms, E. coli, S. aureus and aerobic psychrotrophic counts $<10 \mathrm{CFU} / \mathrm{g}$ sample (estimated values). Moreover, Salmonella sp. was absent in all treatments. These results were expected since good manufacturing practices were prioritised throughout the processing to ensure the microbiological safety of the food product. Furthermore, the nuggets were cooked (pasteurised) to a minimum internal temperature of
$72{ }^{\circ} \mathrm{C}$, followed by frozen storage $\left(-18{ }^{\circ} \mathrm{C}\right)$. In a related investigation, Akesowan (2016) did not find microbial growth in control nuggets and those reformulated with konjac flour/xanthan gum mixture and shiitake mushrooms powder.

\section{Sensory analyses}

From the sensory analysis of the different chicken nugget treatments (with or without the addition of chia flour and different salts) (Table 4), Chia and $\mathrm{Chia}+\mathrm{CaCl}_{2}$ treatments presented lower sensory acceptance $(p<0.05)$ for all the evaluated parameters. Chia flour has previously been shown to decrease the acceptance of the internal appearance and overall quality parameters of chicken nuggets (Barros et al., 2018). Nevertheless, the addition of up to $10 \mathrm{~g} / 100 \mathrm{~g}$ chia flour was considered acceptable, although, above this proportion $(\geq 10 \mathrm{~g} / 100 \mathrm{~g})$, a decrease in the scores for aroma and flavour attributes were observed (Barros et al., 2018). In other work, although frankfurters incorporated with chia flour $(10 \mathrm{~g} / 100 \mathrm{~g})$ were accepted by the consumers, low scores were assigned to all evaluated attributes (Pintado et al., 2016a). The darker colour (Fig. 1) and flavour (scores $<5$ ) of the products are the main reasons for the lower sensory acceptance of the chicken nuggets added with chia flour, in the present study. It is worth mentioning, that the consumers did not observe differences $(p>0.05)$ in internal appearance between the Control and $\mathrm{CaCl}_{2}$ nuggets. Different strategies to incorporate chia into meat products are described in the literature, as exemplified by Heck et al. (2017), who studied beef burger with 50\% substitution of pork back fat by chia oil microparticles $(25 \mathrm{~g} / 100 \mathrm{~g}$ chia oil and $2 \%$ sodium alginate solution). Other researchers used emulsion gels containing chia flour, as a partial $(5 \mathrm{~g} / 100 \mathrm{~g}$; Pintado et al., 2016b) and total substitute $(20 \mathrm{~g} / 100 \mathrm{~g}$; Pintado et al., 2018) for pork back fat in frankfurters and fresh sausages, respectively. However, all three studies verified that the colour and flavour were the attributes most rejected by the consumers.

Although the reformulated chicken nuggets containing chia flour had a lower mean sensory acceptance based

\begin{tabular}{|c|c|c|c|c|c|}
\hline \multirow[t]{2}{*}{ Parameters } & \multicolumn{5}{|c|}{ Treatments } \\
\hline & Control & $\mathrm{CaCl}_{2}$ & Chia & $\mathrm{Chia}+\mathrm{CaCl}_{2}$ & SEM \\
\hline Internal appearance & $7.90^{\mathrm{a}}$ & $7.93^{a}$ & $4.49^{b}$ & $4.81^{\mathrm{b}}$ & 0.14 \\
\hline Aroma & $7.70^{\mathrm{a}}$ & $7.59^{a}$ & $6.25^{b}$ & $6.30^{\mathrm{b}}$ & 0.13 \\
\hline Texture & $7.83^{\mathrm{a}}$ & $7.66^{a}$ & $6.29^{b}$ & $6.59^{b}$ & 0.14 \\
\hline Flavour & $7.93^{\mathrm{a}}$ & $7.84^{\mathrm{a}}$ & $4.76^{b}$ & $4.64^{b}$ & 0.16 \\
\hline Overall quality & $7.94^{\mathrm{a}}$ & $7.83^{a}$ & $5.19^{b}$ & $5.25^{b}$ & 0.14 \\
\hline
\end{tabular}

${ }^{a, b}$ Equal letters on the same row indicate that there is no significant difference at 5\%. SEM: Standard error of mean. Control-1.5 g/100g $\mathrm{NaCl}+20 \mathrm{~g} / 100 \mathrm{~g}$ chicken skin; $\mathrm{CaCl}_{2}-0.375 \mathrm{~g} / 100 \mathrm{~g} \mathrm{NaCl}+0.712$ $\mathrm{g} / 100 \mathrm{~g} \mathrm{CaCl}$; Chia-10 g/100 g chicken skin $+10 \mathrm{~g} / 100 \mathrm{~g}$ chia flour; $\mathrm{Chia}+\mathrm{CaCl}_{2}-0.375 \mathrm{~g} / 100 \mathrm{~g} \mathrm{NaCl}+0.712 \mathrm{~g} / 100 \mathrm{~g} \mathrm{CaCl}_{2}+10 \mathrm{~g} / 100 \mathrm{~g}$ chia flour 


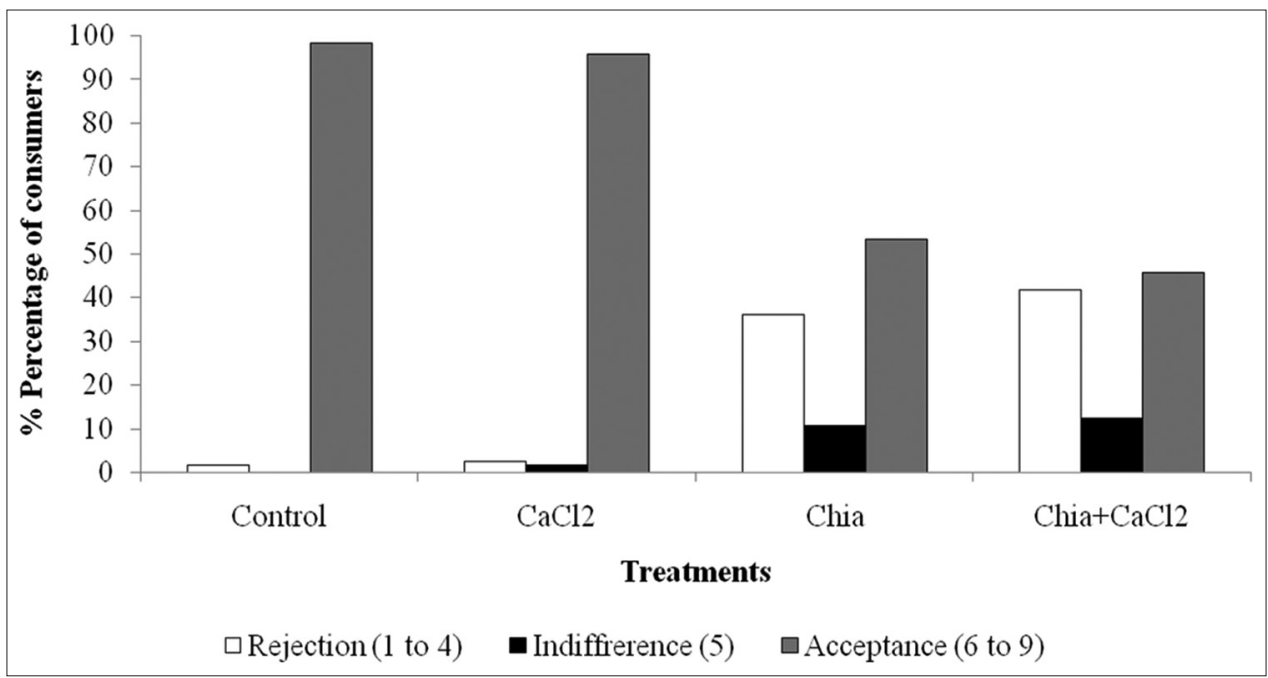

Fig 2. Graphic representation of the acceptance (overall quality), rejection and indifference levels for each treatment of chicken nuggets. Control - $1.5 \mathrm{~g} / 100 \mathrm{~g} \mathrm{NaCl}+20 \mathrm{~g} / 100 \mathrm{~g}$ chicken skin; $\mathrm{CaCl}_{2}-0.375 \mathrm{~g} / 100 \mathrm{~g} \mathrm{NaCl}+0.712 \mathrm{~g} / 100 \mathrm{~g} \mathrm{CaCl}$; Chia - $10 \mathrm{~g} / 100 \mathrm{~g}$ chicken skin + $10 \mathrm{~g} / 100 \mathrm{~g}$ chia flour; Chia $+\mathrm{CaCl}_{2}-0.375 \mathrm{~g} / 100 \mathrm{~g} \mathrm{NaCl}+0.712 \mathrm{~g} / 100 \mathrm{~g} \mathrm{CaCl}_{2}+10 \mathrm{~g} / 100 \mathrm{~g}$ chia flour.

on the acceptance, rejection and indifference levels (considering the overall quality attribute) than the control nuggets (Fig. 2), 46\% (Chia $+\mathrm{CaCl}_{2}$ treatment) and 53\% (Chia treatment) of the consumers considered these samples acceptable (mean score $>6=$ like slightly). Therefore, these products may be accepted in the market by part of the population since around $50 \%$ of the consumers who evaluated the developed nuggets considered these products as acceptable. It is noteworthy that the consumption of the $\mathrm{Chia}+\mathrm{CaCl}_{2}$ nuggets can provide health benefits to the consumers because of the "high omega-3" and "reduced sodium" contents. Since today's consumers are looking for healthier products (de Almeida et al., 2016) and that these same consumers tend to accept these foods despite the lower sensory appeal (Tuorila and Cardello, 2002), the $\mathrm{Chia}+\mathrm{CaCl}_{2}$ nuggets might succeed in the market.

Contrarily, it could be expected that the $\mathrm{CaCl}_{2}$ sample is rejected by the consumers, owing to the characteristic bitter taste of the calcium salt (Lawless et al., 2004). However, the amount of $\mathrm{CaCl}_{2}$ used to substitute the $\mathrm{NaCl}$ while maintaining the same ionic strength (0.256), did not affect $(p>0.05)$ the acceptability of the chicken nuggets relative to the Control treatment (Table 4 and Fig. 2). Probably, the strong and pleasant flavour presented by a deep-fried product, like nuggets, overcame any possible flavour defect originating from the addition of the $\mathrm{CaCl}_{2}$. Different from the present study, the overall acceptability score of dry fermented sausages was lowered when reformulated as low-sodium products containing $50 \% \mathrm{NaCl}$ and $50 \% \mathrm{CaCl}_{2}$ (dos Santos et al., 2015). Likewise, Armenteros et al. (2012) reported a lower sensory acceptance in dry-cured hams prepared with blends of salts containing $\mathrm{KCl}$ and $\mathrm{CaCl}_{2}$.

\section{CONCLUSION}

The addition of chia flour $(10 \mathrm{~g} / 100 \mathrm{~g})$ and the replacement of $75 \%$ of $\mathrm{NaCl}$ with $\mathrm{CaCl}_{2}$, with equivalent ionic strength to $1.5 \% \mathrm{NaCl}$, in chicken nuggets, can be considered good strategies to obtain a healthier meat product, providing high $\alpha$-linolenic (omega-3) and low sodium contents. Although the addition of chia flour $(10 \mathrm{~g} / 100 \mathrm{~g})$ increased the protein content in chicken nuggets, the sensory acceptance decreased. Therefore, a replacement of chicken skin by chia flour at less than $10 \mathrm{~g} / 100 \mathrm{~g}$ may be recommended for chicken nuggets. Besides, it is recommended to substitute $75 \% \mathrm{NaCl}$ for $\mathrm{CaCl}_{2}$ since this strategy both maintained the acceptability of the meat product and reduced the sodium content by more than $40 \%$.

\section{ACKNOWLEDGEMENTS}

The authors gratefully acknowledge the Coordenação de Aperfeiçoamento de Pessoal de Nível Superior - Finance Code 001 (CAPES, Brazil) for the doctoral scholarship granted to the first author (JC Barros). Also to the Fundação de Amparo à Pesquisa do Estado de São Paulo [São Paulo Research Foundation (FAPESP, Brazil)] for supporting the research (Process2015/12429-7). The authors also thank the companies New Max (Brazil) and Cori Ingredientes (Brazil) for their donations. JC Barros, I Rodrigues, FAL Carvalho and MA Trindade are members of the Productos Cárnicos Más Saludables (Healthy Meat) network, funded by the Ibero-American Programme on Science and Technology for Development (CYTED) (Reference 119RT0568).

\section{Declaration of interest statement}

The authors declare no conflicts of interest. 


\section{Authors' contribution}

Authors contributed equally to this study.

\section{REFERENCES}

Akesowan, A. 2016. Production and storage stability of formulated chicken nuggets using Konjac flour and shiitake mushrooms. J. Food Sci. Technol. 53: 3661-3674.

Aliño, M., R. Grau, F. Toldrá and J. M. Barat. 2010. Physicochemical changes in dry-cured hams salted with potassium, calcium and magnesium chloride as a partial replacement for sodium chloride. Meat Sci. 86: 331-336.

AOAC. 2000. Official Methods of Analysis of AOAC International. $17^{\text {th }}$ ed. AOAC International, Gaithersburg, MD.

Armenteros, M., M. C. Aristoy, J. M. Barat and F. Toldrá. 2012. Biochemical and sensory changes in dry-cured ham salted with partial replacements of $\mathrm{NaCl}$ by other chloride salts. Meat Sci. 90: 361-367.

Barros, J. C., T. S. Gois, M. A. Pires, I. Rodrigues and M. A. Trindade. 2019. Sodium reduction in enrobed restructured chicken nuggets through replacement of $\mathrm{NaCl}$ with $\mathrm{CaCl}_{2}$. J. Food Sci. Technol. 56: 3587-3596.

Barros, J. C., P. E. S. Munekata, M. A. Pires, I. Rodrigues, O. S. Andaloussi, C. E. C. Rodrigues and M. A. Trindade. 2018. Omega-3- and fibre-enriched chicken nuggets by replacement of chicken skin with chia (Salvia hispanica L.) flour. LWT Food Sci. Technol. 90: 283-289.

Bligh, E, G. and W. J. Dyer. 1959. A rapid method of total lipid extraction and purification. Can. J. Biochem. Physiol. 37: 911917.

Brasil. 2003. Resolução RDC n 359, de 23 de dezembro de 2003. Aprova Regulamento Técnico de Porções de Alimentos Embalados para Fins de Rotulagem Nutricional. Diário Oficial da União 26 dez. 2003. Ministério da Saúde, Brasília, Brazil.

Brasil. 2012. RDC $n^{\circ} 54$ de 12 de Novembro de 2012. Dispõe Sobre o Regulamento Técnico Sobre Informação Nutricional Complementar. Anexo Regulamento Técnico Mercosul Sobrein form ação Nutricional Complementar (Declarações de Propriedades Nutricionais). Diário Oficial de União 19 nov. 2012. Ministério da Saúde, Brasília, Brazil.

Brasil. 2013. Extrato de Compromisso. Termo de Compromisso que firmam Entre si a União, por Intermédio do Ministério da Saúde, a Associação Brasileira das Indústrias de Alimentos $A B I A$, Associação Brasileira das Indústrias de Queijo-ABIQ, Associação Brasileira da Indústria Produtora e Exportadora de Carne Suína-ABIPECS, Sindicato da Indústria de Carne e Derivados no Estado de São Paulo -SINDICARNES e União Brasileira de Avicultura-UBABEF Com a Finalidade de dar Continuidade ao Estabelecimento de Metas Nacionais para a Redução do teor de Sódio em Alimentos Processados no Brasil. Diário Oficial da União13 dez. 2013. Ministério da Saúde, Brasília, Brazil.

Campagnol, P. C. B., B. A. dos Santos, J. M. Lorenzo and A. J. Cichoski. 2017. A combined approach to decrease the technological and sensory defects caused by fat and sodium reduction in Bolognatype sausages. Food Sci. Technol. Int. 23: 471-479.

Capitani, M. I., V. Spotorno, S. M. Nolasco and M. C. Tomás. 2012. Physicochemical and functional characterization of by-products from chia (Salvia hispanica L.) seeds of Argentina. LWT Food Sci. Technol. 45: 94-102.

Choi, Y. S., D. J. Han, J. H. Choi, K. E. Hwang, D. H. Song, H. W. Kim, Y. B. Kim and C. J. Kim. 2016. Effect of chicken skin on the quality characteristics of semi-dried restructured jerky. Poult. Sci. 95: 1198-1204.

Coates, W. and R. Ayerza. 1996. Production potential of chia in North Western Argentina. Ind. Crops Prod. 5: 229-233.

Commission Regulation (EU). 2010. No. 116/2010 of 9 February 2010 amending regulation (EC) No. 1924/2006 of the European parliament and of the council with regard to the list of nutrition claims. Off. J. Eur. Union. L. 37: 16-18.

Costantini, L., L.Lukšič, R. Molinari, I. Kreft, G. Bonafaccia, L. Manzi and N. Merendino. 2014. Development of gluten-free bread using tartary buckwheat and chia flour rich in flavonoids and omega-3 fatty acids as ingredients. Food Chem. 165: 232-240.

Cunniff, P. (Ed.). 1998. Official Methods of Analysis of AOAC International. $16^{\text {th }}$ ed., Ch. 16. AOAC International, Arlington, VA, pp. 26-27.

de Almeida, M. A., N. D. M. Villanueva, J. S. S. Pinto, E. Saldaña and C. J. Contreras-Castillo. 2016. Sensory and physicochemical characteristics of low sodium salami. Sci. Agric. 73: 347-355.

Devatkal, S. K., D. M. Kadam, P. K. Naik and J. Sahoo. 2011. Quality characteristics of gluten-free chicken nuggets extended with sorghum flour. J. Food Qual. 34: 88-92.

dos Santos, B. A., P. C. B.Campagnol, A. G. da Cruz, M. A. Morgano, R. Wagner and M. A. R. Pollonio. 2015. Is there a potentia consumer market for low-sodium fermented sausages? J. Food Sci. 80: S1093-S1099.

dos Santos, B. A., P. C. B. Campagnol, M. B. Fagundes, R. Wagner and M. A. R. Pollonio. 2017. Adding blends of $\mathrm{NaCl}, \mathrm{KCl}$, and $\mathrm{CaCl}_{2}$ to low-sodium dry fermented sausages: Effects on lipid oxidation on curing process and shelf life. J. Food Qual. 2017: 7085798

European Commission. 2006. Regulation (EC) No. 1924/2006 of the European parliament and of the council of 20 December 2006 on nutrition and health claims made on foods. Off. J. Eur. Union. L. 404: 9-25.

FAO/WHO. 2008. Interim Summary of Conclusions and Dietary Recommendations on Total Fat and Fatty Acids. From the Joint FAO/WHO Expert Consultation on Fats and Fatty Acids in Human Nutrition, Geneva, Switzerland.

Fernández-Ginés, J. M., J. Fernández-López, E. Sayas-Barberá and J. A. Pérez-Alvarez. 2005. Meat products as functional foods: A review. J. Food Sci. 70: R37-R43.

Galvão, M. T. E. L., D. B. Moura, A. C. S. Barretto and M. A. R. Pollonio. 2014. Effects of micronized sodium chloride on the sensory profile and consumer acceptance of turkey ham with reduced sodium content. Food Sci. Technol. 34: 189-194.

Gimeno, O., I. Astiasarán and J. Bello. 1999. Influence of partial replacement of $\mathrm{NaCl}$ with $\mathrm{KCl}$ and $\mathrm{CaCl}_{2}$ on texture and color of dry fermented sausages. J. Agric. Food Chem. 47: 873-877.

Hamm, R. 1986. Functional properties of the myofibrillar system and their measurements. In: P. J. Bechtel (Ed.), Muscle as Food. Academic Press, Orlando, FL, pp. 135-199.

He, F. J., N. R. C. Campbell and G. A. MacGregor. 2012. Reducing salt intake to prevent hypertension and cardiovascular disease. Rev. Panam. Salud Publica. 32: 293-300.

Heck, R. T., R. G. Vendruscolo, M. A. Etchepare, A. J. Cichoski, C. R. de Menezes, J. S. Barin, J. M. Lorenzo, R. Wagner and P. C. B. Campagnol. 2017. Is it possible to produce a low-fat burger with a healthy $n-6 / n-3$ PUFA ratio without affecting the technological and sensory properties? Meat Sci. 130: 16-25

Horita, C. N., V. C. Messias, M. A. Morgano, F. M. Hayakawa and M. A. R. Pollonio. 2014. Textural, microstructural and sensory properties of reduced sodium frankfurter sausages containing 
mechanically deboned poultry meat and blends of chloride salts. Food Res. Int. 66: 29-35.

Horita, C. N., M. A. Morgano, R. M. S. Celeghini and M. A. R. Pollonio. 2011. Physico-chemical and sensory properties of reduced-fat mortadella prepared with blends of calcium, magnesium and potassium chloride as partial substitutes for sodium chloride. Meat Sci. 89: 426-433.

Jiménez-Colmenero, F., J. Carballo and S. Cofrades. 2001. Healthier meat and meat products: Their role as functional foods. Meat Sci. 59: 5-13.

Kim, H. Y., K. J. Kim, J. W. Lee, G. W. Kim, J. H. Choe, H. W. Kim, Y. Yoon and C. J. Kim. 2015. Quality evaluation of chicken nugget formulated with various contents of chicken skin and wheat fiber mixture. Korean J. Food Sci. Anim. Resour. 35: 19-26.

Krug, F. J. and F. R. P. Rocha. 2016. Métodos de Preparo de Amostras Para Análise Elementar. $1^{\text {st }}$ ed. Editora SBQ, São Paulo, Brazil.

Kushida, M. M. 2005. Validação de Métodos Laboratoriais: Avaliação do Sistema $\mathrm{Bax}^{\circledR}$ de Análise de Salmonella sp em Alimentos por Reação de Polimerase em Cadeia (PCR). (Dissertation). Universidade Estadual de Campinas, São Paulo, Brasil.

Lawless, H. T., F. Rapacki, J. Horne, A. Hayesand and G. Wang. 2004. The taste of calcium chloride in mixtures with $\mathrm{NaCl}$, sucrose and citric acid. Food Qual. Pref. 15: 83-89.

Lazic, I. B., M. Raseta, D. Nikolic, M. Lukic, D. Karan and S. Lilic. 2015. Reducing the sodium chloride content in chicken pate by using potassium and ammonium chloride. Procedia Food Sci. 5: $22-25$.

Mesías, M., F. Holgado, G. Márquez-Ruiz and F. J. Morales. 2016. Risk/benefit considerations of a new formulation of wheat-based biscuit supplemented with different amounts of chia flour. LWT Food Sci. Technol. 73: 528-535.

Pintado, T., A. M. Herrero, F. Jiménez-Colmenero, C. P. Cavalheiro, C. Ruiz-Capillas. 2018. Chia and oat emulsion gels as new animal fat replacers and healthy bioactive sources in fresh sausage formulation. Meat Sci. 135: 6-13.

Pintado, T., A. M. Herrero, F. Jiménez-Colmenero and C. RuizCapillas. 2016a. Strategies for incorporation of chia (Salvia hispanica L.) in frankfurters as a health-promoting ingredient. Meat Sci. 114: 75-84.

Pintado, T., A. M. Herrero, C. Ruiz-Capillas, M. Triki, P. Carmona and F. Jiménez-Colmenero. 2016b. Effects of emulsion gels containing bioactive compounds on sensorial, technological, and structural properties of frankfurters. Food Sci. Technol. Int. 22: 132-145.

Puolanne, E. and J. Peltonen. 2013. The effects of high salt and low $\mathrm{pH}$ on the water-holding of meat. Meat Sci. 93: 167-170.

Ruusunen, M., J. Vainionpää, M. Lyly, L. Lähteenmäki, M. Niemistö, R.
Ahvenainen and E. Puolanne. 2005. Reducing the sodium content in meat products: The effect of the formulation in low-sodium ground meat patties. Meat Sci. 69: 53-60.

Schut, J. 1976. Meat emulsions. In: S. Friberg (Ed.) Food Emulsions. Marcel Dekker, New York, pp. 385-458.

Segura-Campos, M. R., N. Ciau-Solís, G. Rosado-Rubio, L. ChelGuerrero and D. Betancur-Ancona. 2014. Physicochemical characterization of chia (Salvia hispanica) seed oil from Yucatán, México. Agric. Sci. 5: 220-226.

Shirai, N., H. Suzuki and S. Wada. 2005. Direct methylation from mouse plasma and from liver and brain homogenates. Anal. Biochem. 343: 48-53.

Simopoulos, A. P. 2004. Omega-6/omega-3 essential fatty acid ratio and chronic diseases. Food Rev. Int. 20: 77-90.

Simopoulos, A. P., A. Leaf and N. Jr. Salem. 1999. Essentiality of and recommended dietary intakes for omega- 6 and omega-3 fatty acids. Ann. Nutr. Metab. 43: 127-130.

Tuorila, H. and A. V. Cardello. 2002. Consumer responses to an off-flavor in juice in the presence of specific health claims. Food Qual. Pref. 13: 561-569.

Verma, A. K., R. Banerjee and B. D. Sharma. 2012a. Quality of low fat chicken nuggets: Effect of sodium chloride replacement and added chickpea (Cicer arietinum L.) hull flour. Asian-Australas. J. Anim. Sci. 25: 291-298.

Verma, A. K., R. Banerjee and B. D. Sharma. 2015. Quality characteristics of low fat chicken nuggets: Effect of salt substitute blend and pea hull flour. J. Food Sci. Technol. 52: 2288-2295.

Verma, A. K., B. D. Sharma and R. Banerjee. 2010. Effect of sodium chloride replacement and apple pulp inclusion on the physicochemical, textural and sensory properties of low fat chicken nuggets. LWT. Food Sci. Technol. 43: 715-719.

Verma, A. K., B. D. Sharma and R. Banerjee. 2012b. Quality characteristics of low-fat chicken nuggets: Effect of common salt replacement and added bottle gourd (Lagenaria siceraria L.). J. Sci. Food Agric. 92: 1848-1854.

WHO/FAO. 1994. Fats and Oils in Human Nutrition. Report of a Joint FAO/WHO Expert Consultation; 1993 Oct 19-26. Rome, Italy. FAO Food and Nutrition Paper, No. 57. FAO Publishing Management Group, Rome.

Willett, W. C. 2012. Dietary fats and coronary heart disease. J. Intern. Med. 272: 13-24.

Yang, H. H. L. and H. T. Lawless. 2005. Descriptive analysis of divalent salts. J. Sens. Stud. 20: 97-113.

Zanardi, E., S. Ghidini, M. Conter and A. lanieri. 2010. Mineral composition of Italian salami and effect of $\mathrm{NaCl}$ partial replacement on compositional, physico-chemical and sensory parameters. Meat Sci. 86: 742-747. 